\title{
Sudan Academy for Banking and Financial Sciences and Its Vision As A Hub of Islamic Finance in Africa
}

\author{
Dr. Magda Ismail Abdel Mohsin
}

International Centre for Education in Islamic Finance (INCEIF), The Global University of Islamic Finance, Malaysia

Dr. Ishraga Khattab

Centre Sudan Academy for Banking and Financial Sciences

Mhd Osama Alchaar

International Centre for Education in Islamic Finance (INCEIF), The Global University of Islamic Finance, Malaysia

\begin{abstract}
:
The practice of Islamic banking has become a fast growing and widespread phenomenon, not only in the Muslim countries, but also in the Non-Muslim countries too, such as UK, USA, Canada and Singapore. The transformation from a conventional form of banking to a banking system based on interest-free banks has generated a great deal of interest to call for Human Capital Development in the field to ensure sustainability, good performance and good competitive market in the Islamic financial industry. Even though Sudan is the pioneer in taking the initiative of Islamizing its financial industry since 1980s, yet we realized that other countries are taking the leading international and regional hub of Islamic finance such as Malaysia in the Asian region and UK in European countries, and recently Canada is also calling to become one of the hub of Islamic finance in the far west. Africa is also highly expected to host many Islamic financial institutions in the near future as there is a great demand for the Islamic financial products. This urged the authors to shed some light on the role of Sudan Academy for Banking and Financial Sciences and its vision to become a hub for Human Capital Development and in promoting Islamic Finance not only in the African region but also in the Arab countries too.
\end{abstract}

Paper type: Research Paper

Keywords: Islamic Finance, Human Capital Development, Islamic Banking Education, Africa, Sudan 


\section{Introduction}

The journey of Sudan Academy for Banking and Financial Sciences (SABFS) as an educational institution and as a human capital development in banking sector started since 1963 with the establishment of the Institute of Banking Studies. During that time the Institute of Banking Studies was established as a result of joint efforts exerted by the Central Bank of Sudan and commercial and specialized banks to provide banks' staff with the skills and knowledge required to cope with the banking system and economic and financial transactions in the country. The curriculum was designed to focus on conventional banking and modern technological systems. With the Islamization notion which took place in Sudan during 1980s (Abdel Mohsin, 2005; Boumediene, 2015; Zaher and Hassan, 2001), Islamic curriculum was integrated within the syllabus in 1993 and the institute was renamed to High Institute for Banking and Financial Studies. In 2006, the need for further development was realized when this institution was transferred into Sudan Academy for Banking and Financial Sciences known as SABFS (http://www.sabfs.edu.sd/). The main role of SABFS is to lead three main centres; the academic programs centre, the banking and financial training centre and the research publishing and consultancy centre.

\subsection{Vision, Missions, Values \& Objectives}

SABFS's vision is to be a pioneer academy for developing and spreading knowledge in Islamic banking and finance industry, at the domestic, regional and international levels. In addition to provide the knowledge of Islamic finance of high academic standards, the SABFS's mission also encourages conducting scientific research and offering consultations to the Islamic finance industry. SABFS also aims to develop practical and modern training programs to its workforce in order to promote the ethical banking profession through formulating high moral standards, honesty, justice and integrity, innovative and excellence in services and teamwork spirit.

In addition, SABFS objectives are as follows: to provide more opportunities in the higher education according to the directives of the Ministry of Higher Education and Scientific Research, to focus on studies of unique nature, especially in those areas of science and technology that are linked to development needs and scientific research.

\subsection{Historical Development}

The Institute of Banking Studies was established in the 1960s and the main objective of establishing this institute was to provide education and training for bankers (Rogers, 1975). In 1990s, with a request from the governor of central bank of Sudan, a high level committee was established to restructure the institute in conformity with the growing Islamic banking system and rising up the position of the institute to make it accredited locally and internationally (Bovens et al., 2002). In 1993, the first intake was 164 students who graduated in 1997. Later on and with the transformation of this institution into Sudan Academy for Banking and Financial Sciences (SABFS) in 2006 the total number of students increased to reach 9409 . Out of this number 4845 students chose to take the undergraduate programs, 3353 students took under-graduate diploma and 1211 students embarked on the postgraduate programs.

International Journal of Management and Applied Research, 2017, Vol. 4, No. 1 


\subsection{Islamization of Islamic Banking}

The year 1978 had witnessed the establishment of the first Islamic bank in the Sudan, Faisal Islamic bank, which marked the first step to Islamize all Sudanese banks later (Abdel Mohsin, 2005; Babyesiza, 2015; Zaher and Hassan, 2001). The success of Faisal Islamic Bank led to emergence of a number of Islamic banks such as Tadamon Islamic bank, the Sudanese Islamic bank, the Islamic Cooperative development bank and Albaraka bank, all these banks succeeded in attracting more depositors, and hence, more branches were opened over all states of Sudan. In 1983, the government applied Shariah rules on all transaction that lead to Islamization of all banks and interest was outlawed (Zaher and Hassan, 2001) and since then the country has been applying ribafree principles in banking transactions. Over past few decades, the banking system in Sudan has undergone substantial privatization, liberalization, and restructuring (Ibrahim, 2006). As of 2006, the Sudanese Banking system is fully Islamized, which comprised of 21 national banks with 533 branches (Ibrahim, 2006). The Islamization necessitated the need for human capital development (Haneef, 2009) which is provided through SABFS as well as other colleges and universities in Sudan providing similar programs in Islamic finance. Equipping the banking and financial services sector with pool of talents has been the mission of SABFS, and thus the main focus of this study is to examine the learning experience of its students as well as students' perception regarding its prospects.

\section{SABFS's Academic Programmes}

SABFS provides various undergraduate and postgraduate programs which are taught by 31 members of academic staff, one professor, seven associate professors, eight assistant professors, five fellowship and ten lecturers. The details of the undergraduate and postgraduate programs are as follows:

\subsection{Undergraduate Programs}

These undergraduate programs are divided into two Bachelor Degrees consisting of three programs and Bachelor Honours which is also consist of three programs both to be completed within 4 years and are divided into 8 semesters, with 2 semesters per academic year. The duration of each semester is 15 weeks. SABFS follows the fulltime system, which requires student attendance of not less than $75 \%$ of the lectures for each course. The admission requirements for these programs are as follows:

- Pass the Sudan Secondary School Certificate (academic - technical commercial) or its equivalent and achieve $70 \%$ at minimum as graduation average.

- Pass the seven subjects from which the admission percentage is calculated.

- Pass Arabic language, English language, Mathematics and Islamic studies.

- The satisfaction of all above requirements is one certificate and under one index number and date.

Source: Sudan Academy for Banking and Financial Sciences (2013)

International Journal of Management and Applied Research, 2017, Vol. 4, No. 1 
Table 1: Undergraduate Programmes 1997-2016

\begin{tabular}{llr}
\hline & PROGRAMMES & No. of students \\
\hline 1 & BSc in Banking \& Financial Studies & 3715 \\
2 & BSc in Banking \& Financial Studies (with specialisation on insurance) & 52 \\
3 & BSc in Banking Information System & 670 \\
4 & BSc in Accounting and Finance & 190 \\
5 & BSc in Business Administration & 144 \\
6 & BSc in Economics & 74 \\
& Total & 4845 \\
\hline
\end{tabular}

As seen in Table 1, the number of Students registered for BSc Degree in Banking \& financial studies is 3715 and the Number of Students registered for BSc Degree in Banking \& Financial Studies (with specialisation on insurance) is only 52, while the Number of Students registered in BSc degree in Banking Information System is 670. With reference to the number of Students registered for the BSc Accounting and Finance is 190 and the Number of Students registered in BSc Business Administration is 144 while 74 students registered in BSc Economics.

\subsection{Undergraduate Diploma (Duration: Three Years for Each stream)}

SABFS offers two undergraduate diploma programs: Diploma in Banking and Financial Studies and Diploma in Banking Information Systems Studies. The admission requirements for undergraduate diploma are:

- Pass the Sudan Secondary School Certificate (academic - technical - commercial) or its equivalent and achieve $70 \%$ at minimum as graduation average.

- Pass the seven subjects from which the admission percentage is calculated.

- Pass Mathematics.

- The satisfaction of all above requirements is one certificate and under one index number and date.

The duration for studying the Bachelor program is 3 years divided into 6 semesters, 2 semesters per academic year. The duration of each semester is 15 weeks. SABFS follows the full-time system, which requires student attendance of not less than $75 \%$ of the lectures for each course.

Table 2: Undergraduate Diploma 1997-2016

\begin{tabular}{llr}
\hline PROGRAMS & No. of Students \\
\hline 1 & Diploma in Banking and Financial Studies & 2704 \\
2 & Diploma in Banking Information Systems Studies & 649 \\
& Total & 3353 \\
\hline
\end{tabular}

As seen in table 2, the overall number of Students registered for Diploma in Banking and Financial Studies during (1997-2016) is 2704 while Number of Students registered for Diploma in Banking Information Systems Studies is 649.

\subsection{Postgraduate Programs}

SABFS offers the following postgraduate diploma and master programs in Banking and Financial Studies, Accounting and finance, Banking and financial information systems. In addition to offering Postgraduate Diploma/MBA in the following 
specializations, Microfinance, Marketing of banking and financial services and Management of banking and financial institutions. The Duration of study for these programs is 2 semesters for Postgraduate Diploma and 3 semesters and research for MSc and MBA. The Admission requirements for:

- Postgraduate Diploma/MSc in Banking Studies are a Bachelor degree in (Banking studies, Economics, Banking and Export) from SABFS or its equivalent from other universities with a minimum good grade or pass with at least 2 years of working experience.

- Postgraduate Diploma/MSc in Accounting and finance are a Bachelor degree in (Accounting or cost accounting) from SABFS or its equivalent from other universities with a minimum good grade or pass with at least 2 years of working experience.

- Postgraduate Diploma/MSc in Banking and financial information systems are a Bachelor degree from SABFS or its equivalent from other universities with a minimum good grade or pass with at least 2 years of working experience, and good command of one of the programming language, and efficient use of computer and internet.

- Postgraduate Diploma/MBA are from SABFS or its equivalent from other universities with a minimum good grade or pass with at least 2 years of working experience in the field of speciality, and good command of one of the programming language, and efficient use of computer and internet.

Table 3: Postgraduate Programs 1997-2016

\begin{tabular}{llr}
\hline PROGRAMS & No. of Students \\
\hline 1 & Diploma/MSc in Banking \& Financial Studies & 461 \\
2 & Diploma/MSc in Accounting \& Finance Studies & 308 \\
3 & Diploma/MSc in Banking and Financial Information Systems & 196 \\
4 & Master of Business Administration/Management of Banking \& & 246 \\
& Financial Institutions & 1211 \\
& Total \\
\hline
\end{tabular}

As seen in table 3, the number of students who registered during (1997-2016) in Postgraduate Diploma/MSc in Banking \& Financial Studies is 461 and the Number of students registered in Postgraduate Diploma/MSc in Accounting and Finance is 308, and Number of students registered in Postgraduate Diploma/MSc in Banking and Finance Information Systems is 196 and the Number of students registered in Business Administration is 246.

\section{Methodology}

Human Capital development in the field of Islamic finance is paramount for supporting the success and maintaining the growth and sustainability of the industry, locally and internationally. The following will present the role of SABFS's graduates in creating the foundation for developing the skills needed by the finance industry in general, and Islamic finance particularly. In order to have a general idea about the perspective and/or attitude of samples of Sudanese towards SABFS and how to develop it, two

International Journal of Management and Applied Research, 2017, Vol. 4, No. 1 
surveys were designed both in Arabic and English language and distributed on two samples, for SABFS graduates and the Islamic banking sector employees in Sudan.

The sample of the first survey, which contained 27 questions, was 47 SABFS graduates and we received 33 valid responses, while the second survey contained 16 questions and the sample was 54 Islamic banking employees, mainly from the financial sector, where we received 43 valid responses, so the total of valid responses from the two surveys was 76 questionnaires. All the questionnaires were distributed in their Arabic version to guarantee a full comprehension by the respondents, while results were analyzed and presented using the English version of the questionnaire which is the exact translation of the Arabic one. We used both of Microsoft Excel and the Statistical Package for the Social Sciences (SPSS) for designing, collecting and analyzing the data and getting the descriptive statistics out of it.

As the responses of the survey were limited in number and don't constitute large sample, the findings of this survey don't reflect on the actual and accurate perception of SABFS. However, we think that the results give a general idea and a good glance about the situation behind this survey that could be used as a supporting source or additional base for future decision-making and research.

\section{Research Findings}

\subsection{First Survey: SABFS Graduates Students}

Out of 47 questionnaires distributed to SABFS graduates, 33 graduates responded to this survey. The results of this survey presented according to age, educational degree and current jobs of graduates:

\section{Age Group}

With reference to age in the first sample of respondents, out of 33 SABFs graduates: $52 \%$ were among the age of 20 to 24 years, $21 \%$ are among the age of $25-30$ years, $9 \%$ among the age of 31 to 34 years, $12 \%$ among the age of 35 to 40 years, which show a very good distribution of $94 \%$ of the students are within the age of 20-40, while only $6 \%$ of the students are above 40 years.

Figure 1: Age groups

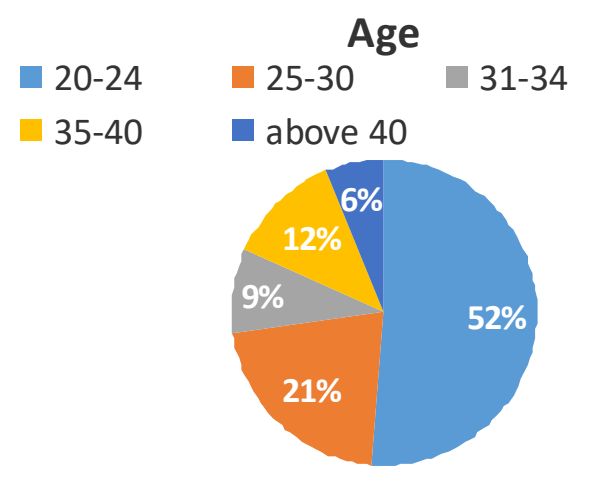

International Journal of Management and Applied Research, 2017, Vol. 4, No. 1 


\section{Highest Educational Qualification}

With reference to the type of education pursued in SABFS, out of 33 graduates: $70 \%$ undertook bachelor degree, 12\% master degree, 9\% postgraduate diploma and 9\% three-years diploma. This indicates that the majority of the respondents spent at least 4 years at SABFS.

Figure 2: Highest Education Qualification

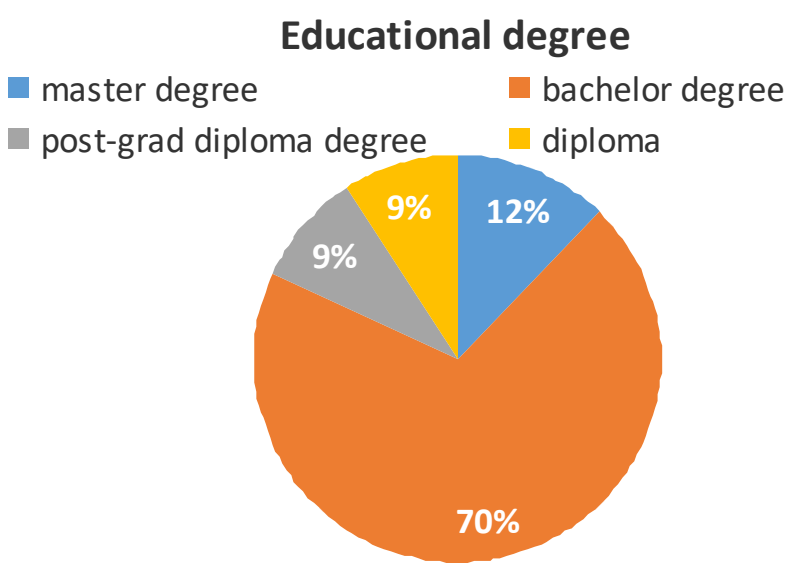

\section{Current Job}

With reference to the current job of the graduates: $30 \%$ of them are working in banks, $3 \%$ of them are in insurance companies, $3 \%$ of them are in commercial companies, and unfortunately $46 \%$ of them are seeking for employment. However, we think that the high percentage of unemployed respondents is influenced by the general economic conditions in Sudan having a growing level of unemployment that reached $19 \%$ in 2015 according to Trading Economics (2017).

Figure 3: Current Job

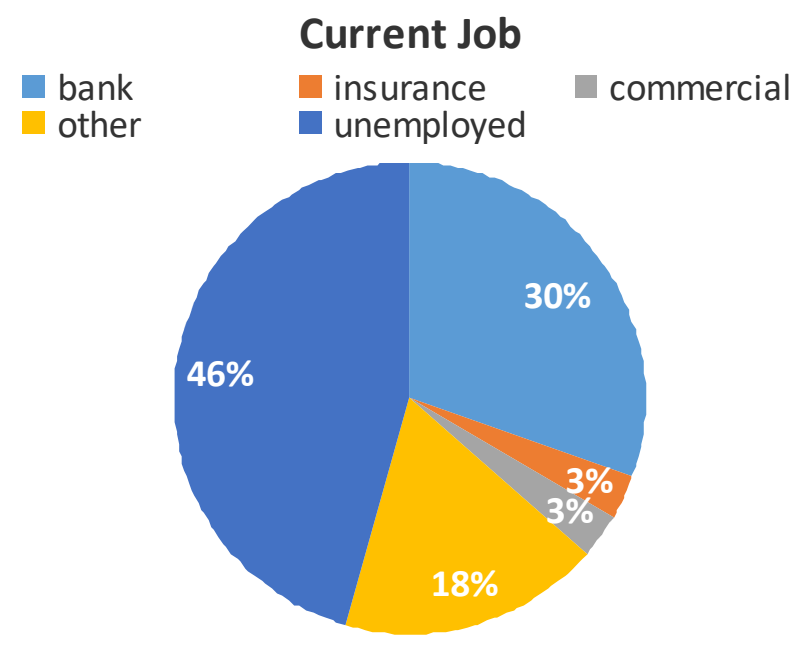

With reference to the following questions table (4) displays the detailed results of the first survey:

International Journal of Management and Applied Research, 2017, Vol. 4, No. 1 
Table 4: Results of $1^{\text {st }}$ Survey - All Numbers in Percentage (\%)

\begin{tabular}{|c|c|c|c|c|c|c|}
\hline & Question & $\begin{array}{l}\text { Strongly } \\
\text { disagree }\end{array}$ & Disagree & Neutral & Agree & $\begin{array}{r}\begin{array}{r}\text { Strongly } \\
\text { agree }\end{array} \\
\end{array}$ \\
\hline 1 & $\begin{array}{l}\text { I joined SABFS because I have } \\
\text { interest in Islamic banking }\end{array}$ & 6.1 & 18.2 & 36.4 & 39.4 & 0 \\
\hline 2 & $\begin{array}{l}\text { I joined SABFS because its } \\
\text { requirements are less than other } \\
\text { universities }\end{array}$ & 6.1 & 36.4 & 27.3 & 27.3 & 3 \\
\hline 3 & $\begin{array}{l}\text { I joined SABFS because it's the best } \\
\text { institution in Sudan for education in } \\
\text { banking/Islamic banking }\end{array}$ & 0 & 6.1 & 18.2 & 60.6 & 15.2 \\
\hline 4 & $\begin{array}{l}\text { As a graduate, SABFS fulfilled my } \\
\text { educational aspirations and objectives }\end{array}$ & 3.0 & 3.0 & 33.3 & 48.5 & 12.1 \\
\hline 5 & $\begin{array}{l}\text { The value added from learning at } \\
\text { SABFS was as or better than } \\
\text { expectations }\end{array}$ & 6.1 & 3.0 & 18.2 & 63.6 & 9.1 \\
\hline 6 & $\begin{array}{l}\text { SABFS is the best source of qualified } \\
\text { HR in Islamic banking in Sudan }\end{array}$ & 3.0 & 6.1 & 24.2 & 48.5 & 18.2 \\
\hline 7 & $\begin{array}{l}\text { Graduating from SABFS has helped } \\
\text { me finding a job in financial sector }\end{array}$ & 3.0 & 6.1 & 27.3 & 57.6 & 6.1 \\
\hline 8 & $\begin{array}{l}\text { Graduates of SABFS find jobs more } \\
\text { easily than other graduates }\end{array}$ & 0 & 3.0 & 15.2 & 63.6 & 18.2 \\
\hline 9 & $\begin{array}{l}\text { SABFS courses need to be } \\
\text { restructured and developed }\end{array}$ & 0 & 9.1 & 18.2 & 54.5 & 18.2 \\
\hline 10 & I think SABFS fees are affordable & 6.1 & 9.1 & 24.2 & 54.5 & 6.1 \\
\hline 11 & $\begin{array}{l}\text { I think that Research Centre at } \\
\text { SABFS is good enough to make it an } \\
\text { international academy }\end{array}$ & 3.0 & 18.2 & 18.2 & 54.5 & 6.1 \\
\hline 12 & $\begin{array}{l}\text { Campus life at SABFS is diversified } \\
\text { and provides rich social experience }\end{array}$ & 18.2 & 15.2 & 9.1 & 48.5 & 9.1 \\
\hline 13 & $\begin{array}{l}\text { I would recommend SABFS to my } \\
\text { friends/relatives }\end{array}$ & 3.0 & 6.1 & 18.2 & 60.6 & 12.1 \\
\hline 14 & $\begin{array}{l}\text { Courses titles and descriptions reflect } \\
\text { the actual contents }\end{array}$ & 6.1 & 12.1 & 15.2 & 63.6 & 3.0 \\
\hline 15 & $\begin{array}{l}\text { SABFS courses are up-to-date with } \\
\text { current market practices }\end{array}$ & 6.1 & 6.1 & 27.3 & 57.6 & 3.0 \\
\hline 16 & $\begin{array}{l}\text { SABFS should be converted into a } \\
\text { regional or international institution }\end{array}$ & 3.0 & 12.1 & 15.2 & 57.6 & 12.1 \\
\hline 17 & $\begin{array}{l}\text { SABFS courses should be offered in } \\
\text { English language }\end{array}$ & 0 & 0 & 12.1 & 54.5 & 33.3 \\
\hline 18 & $\begin{array}{l}\text { SABFS perfor4nce and level will be } \\
\text { better if it accepts non-Sudanese } \\
\text { students }\end{array}$ & 3.0 & 15.2 & 27.3 & 42.4 & 12.1 \\
\hline 19 & $\begin{array}{l}\text { I think that bringing foreigner } \\
\text { lecturers will help the developing of } \\
\text { SABFS. }\end{array}$ & 3.0 & 9.1 & 12.1 & 48.5 & 27.3 \\
\hline
\end{tabular}

International Journal of Management and Applied Research, 2017, Vol. 4, No. 1 
20

Lecturers of SABFS are qualified enough to teach international students

SABFS plays a big role in developing

21 Islamic banking/ finance/ economics in Sudan

22

SABFS is ready to be turned into a global university

23

My general experience at SABFS was:

24

The most useful courses at SABFS were:

What makes SABFS a good place for studying Islamic banking/finance?
3.0

15.2

24.2

48.5

9.1

6.1

3.0

$21.2 \quad 57.6$

6.1

12.1

30.3

39.4

$$
\begin{array}{r}
\text { very poor } \\
0 \%
\end{array}
$$

poor $0 \%$

fair
nough

$54.5 \%$

as

d $27.3 \%$

excellent

$18.2 \%$

banking/

finance

IT courses

languages

course

$15.2 \%$

math

courses

$9.1 \%$

Shariah

courses

$9.1 \%$

average

very good

excellent

$54.5 \%$

$6.1 \%$

$39.4 \%$

$54.5 \%$

foreign

better
infrastructure

$33.3 \%$

better

research

$27.3 \%$

promotion

outside

Sudan

$15.2 \%$

other : $15.5 \%$

\section{Main Findings of First Survey:}

With reference to the twenty seven questions asked to 33 SABFS graduates as seen in table (4), the following are the main findings based on their answers.

- More than $75 \%$ of respondents joined SABFS because it's the most prestigious institution in Sudan for education in Islamic banking/finance.

- More than $70 \%$ of respondents think that the value added by SABFS was better than expected.

- About $80 \%$ of respondents think that graduates of SABFS find job easier than graduates of other universities.

- More than $60 \%$ of respondents think that the courses provided by SABFS need to be restructured and developed further.

- About $60 \%$ of respondents think that fees are affordable, whereas $15 \%$ disagree with that.

- More than 33\% of respondents think that campus life of SABFS is not diversified enough and doesn't provide rich social experience.

- About $65 \%$ of respondents think that the titles of courses reflect on the actual content, with $20 \%$ don't think so.

- About $60 \%$ of respondents think that courses are up-to-date, whereas $13 \%$ don't think so.

- About $70 \%$ of respondents think that SABFS should be converted into a regional or international institution.

- More than $85 \%$ of respondents think that courses should be taught in English language. 
- About $50 \%$ of respondents think that SABFS performance will be better if it accepts non-Sudanese students, however $18 \%$ disagree with that.

- About $75 \%$ of respondents think that bringing foreign lecturers will help developing SABFS.

- More than $50 \%$ of respondents think that SABFS is ready to be turned into a global university.

- $33.3 \%$ of respondents think that the better infrastructure is what SABFS lacks of at the first place.

- $36.5 \%$ of respondents think that the high added value of knowledge is what mostly makes SABFS a good place for learning Islamic banking/finance.

\subsection{Second Survey: 54 Islamic Banking Employees}

Out of 54 questionnaires which had been distributed to Islamic banking employees $\mathbf{4 3}$ responded to this survey. The results of the survey are presented according to age, educational degree and current job of graduates:

\section{Age Groups}

With reference to age of respondents, out of 43 employees: $65 \%$ are among the age of 25 to 30 years, $9 \%$ are among the age of 36-40 years, $16 \%$ among the age of 41 to 45 years, $3 \%$ among the age of 46to 50 years, while only $7 \%$ of the students are above the age of 50 years, so the majority of the respondents were less than 40 years old.

Figure 4: Age Groups

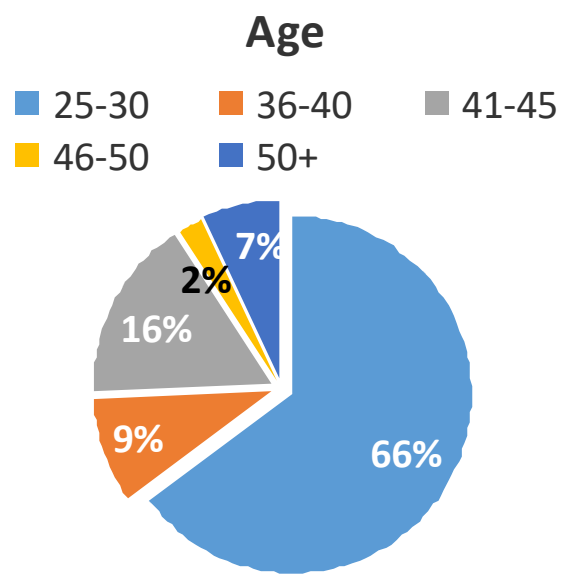

\section{Highest Education Qualifications}

With reference to the type of the employees' education, out of 43 employees, $46 \%$ have bachelor degree, $40 \%$ master degree, $12 \%$ postgraduate diploma and $2 \% \mathrm{PhD}$. This indicates that graduates prefer to be educated to higher levels of education. 
Figure 5: Highest Education Qualifications

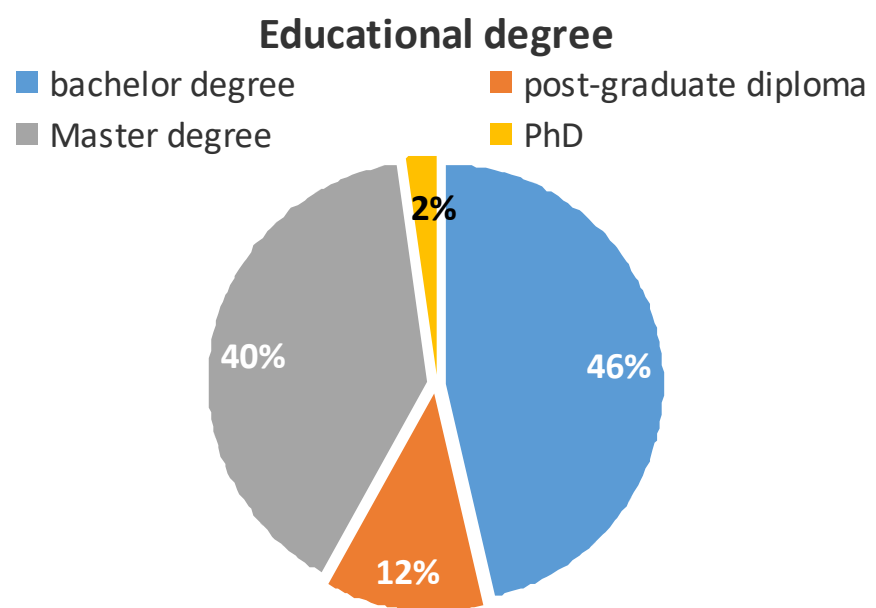

\section{Current Jobs}

With reference to the current job, out of 43 employees: $72 \%$ are working in the areas of finance and insurance, $14 \%$ are academics, $7 \%$ in medicine and engineering and $7 \%$ in religious institutions. Therefore, the majority of the respondents are employed in the finance and insurance sectors which are the main fields of SABFS.

Figure 6: Current Jobs

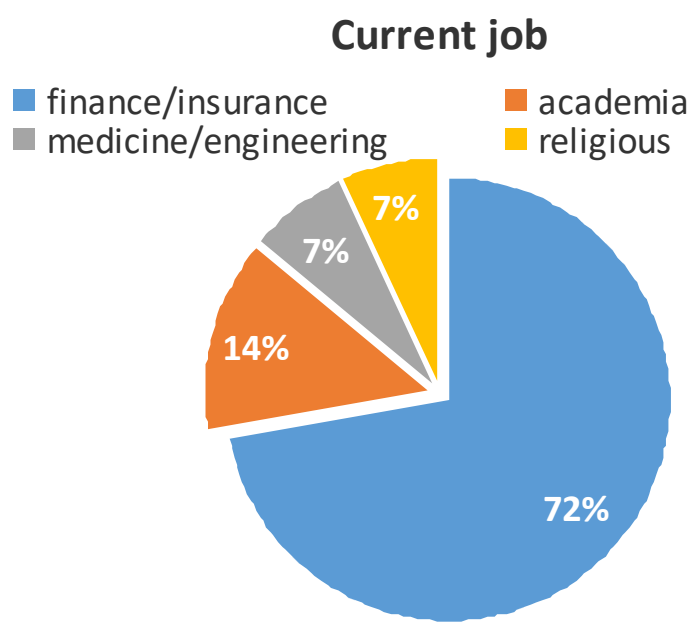

With reference to the following questions table (5) displays the detailed results of the second survey:

Table 5: Results of $2^{\text {nd }}$ Survey - All Numbers in Percentage (\%)

\begin{tabular}{lcccccr}
\hline No. & Question & $\begin{array}{c}\text { Strongly } \\
\text { disagree }\end{array}$ & Disagree & Neutral & Agree $\begin{array}{r}\text { Strongly } \\
\text { agree }\end{array}$ \\
\hline 1 & $\begin{array}{l}\text { I believe in Islamic finance/banking } \\
\text { and think it is significantly different }\end{array}$ & 0 & 4.7 & 7 & 58.1 & 30.2 \\
\hline
\end{tabular}

International Journal of Management and Applied Research, 2017, Vol. 4, No. 1 
from conventional

Sudan is on the top of Islamic

2 finance/banking providers in the

world

9.3

Sudan has enough educational

3 institutions for Islamic

finance/banking

Financial institutions in Sudan are

4 still in need for specialised human resources in Islamic finance/banking

SABFS is the best source of qualified

5 HR in Islamic banking/finance in

Sudan

SABFS plays a big role in

6 developing Islamic banking/finance/economics in Sudan Specialised academies like SABFS

7 are better for education in Islamic finance than universities global not only local

Collaboration with international

9 academic institutions will benefit

SABFS and Sudanese financial sector

10 Without turning into a global academy, SABFS can't develop well

0

Hiring foreign lecturers in SABFS is an important step for developing it

12 SABFS courses should be offered in English language not only in Arabic

SABFS performance and level will

13 be better if it accepts non-Sudanese students

Sudanese students will perform

14 better in an international

environment for studying Islamic

finance

Admission policy in SABFS should

15 be easier to include as much

Sudanese students as possible

0

$4.7 \quad 53.5$

$$
0
$$

$7 \quad 51.2$

$$
2.3
$$

$\begin{array}{llll}0 & 16.3 & 39.5 & 34.9\end{array}$
I'd join or advice someone to join

16 SABFS if it turned into a global academy

$\begin{array}{rrrrr}7 & 16.3 & 18.6 & 37.2 & 20.9 \\ & & & & \\ 20.9 & 25.6 & 18.6 & 16.3 & 18.6\end{array}$

\section{Main Findings of the Second Survey:}


With reference to the sixteen questions asked to a sample of 43 Sudanese employees as seen in table (5), the following are the main findings derived from the respondents replies.

- $50 \%$ of respondents think that Sudan is on the top of Islamic finance and banking providers in the World, whereas 28\% don't support this view.

- About $60 \%$ of respondents think that Sudan has enough educational institutions for Islamic finance/banking, $18 \%$ don't agree.

- More than $83 \%$ of respondents think that financial institutions in Sudan are still in need for specialised human resources in Islamic finance and banking.

- $90 \%$ of respondents agree that specialized academies like SABFS are better for education in Islamic finance and banking than universities.

- $91 \%$ of respondents think that SABFS should be a global academy not only local, and about 50\% think that without turning into global academy, SABFS can't continue to develop well.

- About $85 \%$ of respondents agree that collaboration with international academic institutions will benefit SABFS and Sudanese financial sector.

- $70 \%$ of respondents think that SABFS courses should be offered in English as well, not only in Arabic.

- About $60 \%$ of respondents think that SABFS will benefit from accepting foreign students.

\section{SABFS As A Hub of Human Capital Development In Africa}

As presented above, SABFS played a significant role not only as provider of knowledge on Islamic finance but as a feeder for the Islamic banking sector at a national level. However, and since Islamic banking has been spreading globally, including African countries, we believe that SABFS has the potential to become the hub of human capital development in Africa for African and Arab countries.

Looking at the current development of Islamic finance in the region, SABFS will become the platform for the further expansion and becoming a hub of HCD in Africa. Currently Africa's development needs are greatly aligned with Islamic finance given the continent's infrastructure deficit, paving the way for more sharia-compliant products on the continent. The continent, according to various international studies and reports, has large potential for demand of Islamic finance products. For example, a special report published by International Monetary Fund in 2014 states that "Notwithstanding its presence in a number of African countries, Islamic finance is still at a nascent stage of development in the Sub-Sahara Africa (SSA). The share of Islamic banks is still small, and Islamic capital markets are virtually non-existent (even though there are small sukuk issuances in Sudan, Gambia and Nigeria but yet not documented properly). At the same time, the demand for Islamic finance products is likely to increase in the coming years" (Gelbard et al., 2014: 12). The same report adds: "At present, about half of the region's total population remains to be banked. Furthermore, the Sub-Saharan Africa SSA Muslim population, currently at nearly 250 million people, is projected to reach 386 million in 2030 and financial activities are expected to rise as a share of GDP. It is also expected that many countries will

International Journal of Management and Applied Research, 2017, Vol. 4, No. 1 
introduce Islamic finance activities side-by-side conventional banking. Opportunities for the development of Islamic finance are expected to comprise retail products to small and medium-sized enterprises" (ibid).

The following figure illustrates the emergence of Islamic finance in Sub-Saharan Africa, and the countries with the potential for further development of the industry.

Figure 7: Emergence of Islamic Finance in sub-Saharan Africa

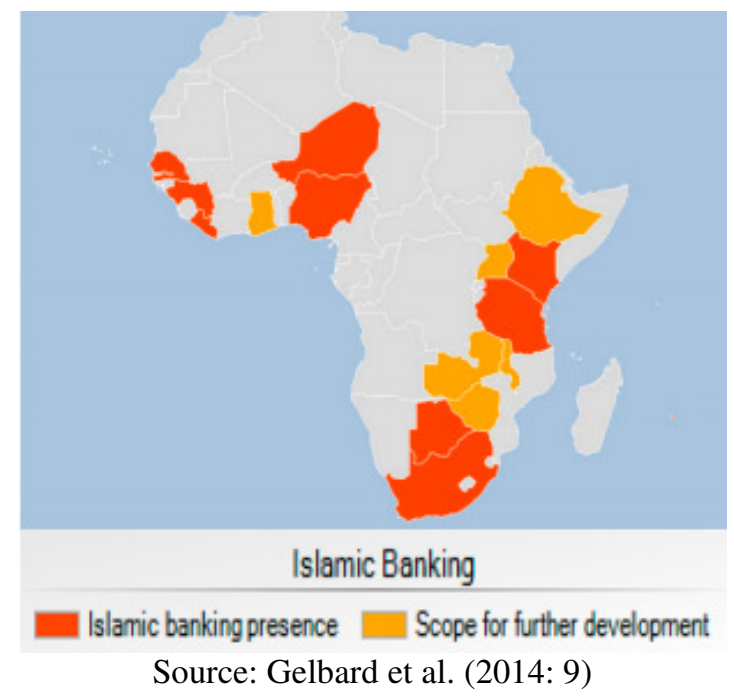

The above mentioned expectation for the proliferation of Islamic finance in Africa necessitates the existence of qualified human capital in all branches of this industry (banking, takaful, sukuk, investments, etc.) and that underpins the importance of a regional educational institution that prepares future human resources to operate and lead such institutions.

With respect to enhancing HCD in Africa, we believe that Sudan has to play a great role in disseminating the knowledge of Islamic finance, since it is the first country to Islamize all its financial system since 1980s. Plus, Sudan is situated at the heart of African region from the geographical point of view. These aspirations can be achieve through enhancing the role of SAFBS by demonstrating significant contribution in the field of HCD at the national level. Hence, it is much recommended for SABFS to strengthen its mission and vision in prompting the Islamic finance in the northern of Africa (Egypt, Libya, Tunisia, Algeria, Morocco) as well as in all African countries (Niger, Nigeria, Senegal, Chad, etc). In this case SABFS will open its door wider for more students from Sudan as well as from the different countries in that region, and hence become the focal point of Islamic finance-centred human capital development in Africa and the Arab world.

\section{Conclusion and Recommendation}

Education in Islamic finance, for building the sufficient and efficient human capital resources, has become a necessity, especially in regions with a high potential for embracing Islamic finance like Africa. Sudan with a fully Islamised banking system 
resting on more than 30 years' experience of Islamic finance practices is a focal point for education in Islamic finance in the region of Africa and the Middle East, provided that adequate academic institutions like SABFS that encourage regulations exist.

We believe that SABFS has the sufficient experience to turn into a regional hub for education in Islamic finance in Africa, and at the later stage to be a recognised authority internationally. However, in order to achieve that, SABFS should follow the below guidelines:

First, SABFS needs to explore an opportunity to upgrade its status from being a local into regional and then international institution. This should be presented in a form of detailed plan which would include reshaping the vision, mission, values and objectives of for the next decade. The considerations of costs and all other requirements needed to be formalised for this transformation process and discussed with all relevant stakeholders (government, regulators, Islamic financial institutions, investors, etc) in the search for their endorsement. In this regard, the INCEIF's experience can be mentioned (Abdel Mohsin, 2016) in getting the financial and logistics support from Bank Negara Malaysia (Central bank of Malaysia) and from local Islamic banks (like MayBank, CIMB, Bank Muamalat and Bank Islam). Similar support could be obtained from Central Bank of Sudan and Islamic financial institutions in Sudan after presenting them with the new vision and the expected incentives and positive results from such expansion.

The expansion or upgrade of the academy requires also various improvements in the physical infrastructure of the academy, the taught courses, the social life at campus, followed by the promotion of the academy locally and externally, and if necessary, hire more lectures either from inside Sudan or from outside the country.

To increase the current number of graduates from SABFS it is much recommended to provide the key programs in Arabic and English. This will ensure that more students will be engaged in study from regional countries in North Africa (Egypt, Libya, Tunisia, Algeria, and Morocco) and other African countries (Niger, Nigeria, Senegal, Chad, etc.).

There should be a revamp of the academy's online presence both in Arabic and English versions as it is the façade of the academy in front of potential students and general public. A revision for the admission fees in the academy and other associated fees is also a necessary step. The new fees structure should balance between the financial sustainability of operating the academy and its affordability for local and international students. It's also highly paramount for the academy to enhance its presence in the social media networks (facebook, twitter, instagram), as they become a daily basis visited portal for millennials (Shall, 2014).

It is also important to ensure collaborations with institutions like INCEIF, ISRA, and IDB/IRTI, as it would be beneficial for both parties. Technical collaboration with Islamic financial institutions in Sudan through training the academy's students (internships, visits, talks) is also crucial in developing the well-rounded human capital. Another important development relates to the growth of the academy's research centre,

International Journal of Management and Applied Research, 2017, Vol. 4, No. 1 
as this will not only benefit the students and lecturers of the academy but will enhance its position and ranking worldwide.

Lastly, enhancing the social life in SABFS is also an important step in raising the profile as based on the survey results (about 33\% of the respondents think that campus life of SABFS is not diversified enough and doesn't provide rich social experience).

To sum up, Sudan and SABFS are capable to become a regional hub for education in Islamic finance in Africa and the Middle East and be influential worldwide. However, this goal can't be achieved without genuine interest in the outlined transformation and the clear objectives supported by sufficient financial, logistic and regulative support. Such hub will, from our point of view, seize the current and future golden opportunity of the proliferation of Islamic finance institutions and products in the World and in Africa particularly.

\section{References}

1. Abdel Mohsin, M. I. (2005), "The Practice of Islamic Banking System in Sudan”, Journal of Economic Cooperation among Islamic Countries, Vol. 26, No. 4, pp. 27-52.

2. Abdel Mohsin, M. I. (2016), Malaysia Islamic Finance Education Report (MIFER), International Council of Islamic Finance Educators ICIEF.

3. Babyesiza, A. (2015), "Higher Education, Identity and Conflict in Sudan", in: University Governance in (Post-)Conflict Southern Sudan 2005-2011, Germany: VS Verlag für Sozialwissenschaften, pp. 43-56. https://doi.org/10.1007/978-3-65808145-4

4. Boumediene, A. (2015), "Financing government budget deficit as a liquidity risk mitigation tool for Islamic Banks: A dynamic approach", International Journal of Islamic and Middle Eastern Finance and Management, Vol. 8, No. 3, pp.329348. https://doi.org/10.1108/IMEFM-04-2014-0038

5. Bovens, M. A. P.; T'Hart, T. B. and Peters, G. (2002), Success and Failure in Public Governance: A Comparative Analysis, UK: Edward Elgar Publishing

6. Gelbard, E.; Hussain, M.; Maino, P.; Yibin Mu, Y. and Yehoue, E. B. (2014), Islamic Finance in Sub-Saharan Africa: Status and Prospects, International Monetary Fund (IMF).

7. Haneef, M.A. (2009), "Islamic banking and finance in the 21st century: selected issues in human capital development", Islam and Civilisational Renewal, Vol. 2 No. 1, pp. 292-302. 
8. Ibrahim, B. E. D. A. (2006), "The "missing links" between Islamic development objectives and the current practice of Islamic banking - the experience of the Sudanese Islamic banks (SIBs)", Humanomics, Vol. 22, No. 2, pp.55 - 66. https://doi.org/10.1108/08288660610669365

9. Rogers, M. and Allott, A. N. (1975), "Introduction and Report of Proceedings", Journal of African Law, Vol. 19, No. 1/2, pp. 3-21. https://doi.org/10.1017/S0021855300006872

10. El-Shall, M. H. (2014), "Net/working: higher education in the age of neoliberalism, crisis and social media", Education + Training, Vol. 56, No. 7, pp. $599-612$. https://doi.org/10.1108/ET-07-2014-0080

11. Sudan Academy for Banking and Financial Sciences (2013), Academy's Guide for 2013-2014, Khartoum, Sudan: Sudan Academy for Banking and Financial Sciences.

12. Trading Economics (2017), Sudan Unemployment Rate 1993-2017, [Online] Available from: http://www.tradingeconomics.com/sudan/unemployment-rate [Accessed on 11 February 2017].

13. Zaher, T. S. and Hassan, M. K. (2001), "A Comparative Literature Survey of Islamic Finance and Banking", Financial Markets, Institutions \& Instruments, Vol. 10, No. 4, pp. 155-199. https://doi.org/10.1111/1468-0416.00044 